\title{
Maternal metal concentration during gestation and pediatric morbidity in children: an exploratory analysis
}

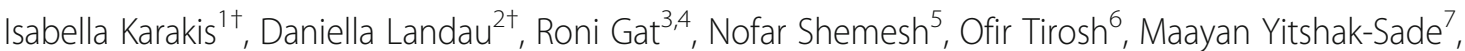
Batia Sarov ${ }^{8}$ and Lena Novack N $^{3,49^{*}}$ (i)

\begin{abstract}
Background: The majority of studies linking exposure to metals with certain health outcomes focus on known toxic metals. Alternatively, this study assesses the extent to which exposure to a wider range of metals during gestation is associated with childhood morbidity.

Methods: We analyzed the concentrations of 25 metals found in urine samples of 111 pregnant women of ArabBedouin origin collected prior to birth. In addition, we collected medical records on their offspring for six years following birth, including every interaction with HMOs, local hospitals, and pharmacies.

Results: The main types of morbidities diagnosed and treated during this period were preterm births, malformations, asthma-like morbidity, cardiovascular and behavioral problems, and obesity. Multivariable analysis showed that offspring born before term were more likely to have been exposed to elevated maternal concentrations of zinc, thallium, aluminum, manganese, and uranium, all with adjusted relative risk above 1.40 for an increase by each quintile. Likewise, children with asthma had been exposed to higher levels of magnesium, strontium, and barium at gestation, while behavioral outcomes were associated with elevated biometals, i.e., sodium, magnesium, calcium, selenium, and zinc, as well as higher levels of lithium, cobalt, nickel, strontium, cadmium, vanadium, arsenic, and molybdenum. A heatmap of adjusted relative risk estimates indicates the considerable implications that exposure to metals may have for preterm birth and developmental outcomes.
\end{abstract}

Conclusions: The current study shows that perinatal exposure to metals is adversely associated with pediatric morbidity. Further such analyses on additional samples are warranted.

Keywords: Heavy metals, Pregnancy, Pediatric, Morbidity, Cohort, Exploratory Analysis

\footnotetext{
* Correspondence: novack@bqu.ac.il

${ }^{\dagger}$ Isabella Karakis and Daniella Landau contributed equally to this work.

${ }^{3}$ Clinical Research Center, Soroka University Medical Center, Beer-Sheva, Israel

${ }^{4}$ Faculty of Health Sciences, Ben-Gurion University of the Negev, Beer-Sheva, Israel

Full list of author information is available at the end of the article
}

(c) The Author(s). 2021 Open Access This article is licensed under a Creative Commons Attribution 4.0 International License, which permits use, sharing, adaptation, distribution and reproduction in any medium or format, as long as you give appropriate credit to the original author(s) and the source, provide a link to the Creative Commons licence, and indicate if changes were made. The images or other third party material in this article are included in the article's Creative Commons licence, unless indicated otherwise in a credit line to the material. If material is not included in the article's Creative Commons licence and your intended use is not permitted by statutory regulation or exceeds the permitted use, you will need to obtain permission directly from the copyright holder. To view a copy of this licence, visit http://creativecommons.org/licenses/by/4.0/ The Creative Commons Public Domain Dedication waiver (http://creativecommons.org/publicdomain/zero/1.0/) applies to the data made available in this article, unless otherwise stated in a credit line to the data. 


\section{Background}

Exposure to heavy metals, the majority of which are highly toxic, can result in severe human morbidities. Lead $(\mathrm{Pb})$, arsenic (As), and mercury $(\mathrm{Hg})$ head the list, followed by aluminum (Al), cadmium (Cd), chromium $(\mathrm{Cr})$, nickel $(\mathrm{Ni})$, titanium $(\mathrm{Ti})$, and others, whose presence is not essential to the human body. As a result, exposure to high concentrations is likely to be adversely associated with health outcomes. At the same time, other metals, including calcium $(\mathrm{Ca})$, cobalt $(\mathrm{Co})$, copper $(\mathrm{Cu})$, iron $(\mathrm{Fe})$, magnesium $(\mathrm{Mg})$, manganese $(\mathrm{Mn})$, molybdenum (Mo), selenium (Se), sodium (Na), and zinc $(\mathrm{Zn})$, are considered essential for human physiology [1]. There is no consensus on the list of essential metals in medical literature; however, some researchers limit them to only $\mathrm{Na}$, potassium (K), Mg, $\mathrm{Ca}, \mathrm{Zn}, \mathrm{Se}$, and $\mathrm{Cu}[2,3]$. This group, also known as "biometals," is characterized by a U-shaped association with health outcomes, whereas no $U$ shape has been reported for non-essential metals [1].

Since toxic metals are known to cross the placenta and blood-brain barrier and deposit in fetal tissues, children are likely to be susceptible to metal exposure early, starting from the time of gestation. For this reason, maternal metal concentration is frequently used as a proxy for that of a fetus when studying health outcomes.

Maternal elevated concentrations of $\mathrm{Al}, \mathrm{As}, \mathrm{Cd}, \mathrm{Hg}$, $\mathrm{Ni}$, and $\mathrm{Mn}$ have been reported in relation to newborn congenital defects at birth [4-7]. Small-for-gestational age (SGA) status at birth has been adversely linked to Cd [8] and As [8, 9]. Likewise, preterm birth was reported associated with $\mathrm{Cd}[10,11]$ and $\mathrm{Pb}[12]$. Nevertheless, the association between $\mathrm{Pb}, \mathrm{Cd}$, As, $\mathrm{Cr}$, or $\mathrm{Hg}$ and preterm birth was not always confirmed [13, 14].

A recent review by Allen provided an evidence of an association between prenatal $\mathrm{Pb}$ exposure and neurological and cognitive impairment [15]. The findings of several other studies support this link for $\mathrm{Pb}[16,17]$, as well as for $\mathrm{Mn}[18,19], \mathrm{Hg}$ [19], As [19], and Cd [20, 21]. However, some contradictory findings have also been reported for $\mathrm{Cd}[19,22-24]$. The lack of association in those cases might have been a result of adjustment to smoking, known to be related to Cd levels [25] as well as to cognitive function [26], and therefore a potential confounder in the association between the two.

Pulmonary function indices and asthma in children were linked with $\mathrm{Pb}[27,28], \mathrm{Mn}, \mathrm{Ni}$, and $\mathrm{Cr}[29,30]$, as well as $\mathrm{Co}$ and $\mathrm{Zn}$ [31]. Likewise, maternal $\mathrm{Pb}$ has been reported in association with elevated blood pressure in 5-year-old children [32] and prenatal exposure to $\mathrm{Cd}-$ with an increased risk of obesity at the age of five [33].

The Bedouin-Arab population of southern Israel is known for elevated rates of childhood morbidity [34] usually related to its low socio-economic status, previous and to some degree still prevalent semi-nomadic life style, temporary housing conditions, high rates of smoking among males, and consanguineous marriages [34, 35].

Because of the vulnerability of the Bedouin-Arab community, the extensive monitoring of hazardous exposures, in an attempt to identify and eliminate modifiable factors related to morbidity, is required. In the current analysis, we aim to explore the possible links between maternal exposure to a wide range of heavy metals at gestation with birth outcomes and the health conditions of 5 to 6-year-old offspring.

\section{Methods}

\section{Study population}

We investigated the subset of a cohort of mothers and their newborns of Bedouin-Arab origin enrolled in our study between Dec 2011 and Mar 2013. Enrollment procedures and characteristics of the study population are described in a previous study [36]. Briefly, all women of Bedouin-Arab origin arriving at the obstetrics emergency department for a delivery at Soroka University Medical Center (SUMC) during the regular working hours were approached by an Arabic-speaking interviewer and invited to participate in the study. Upon signing the informed consent form, the women's spot urine sample was collected, although not all women could comply with this requirement given their condition and a relatively short time to the onset of delivery. The questionnaire on the demographical and clinical characteristics of the women, as well as a description of possible hazardous factors in their immediate household, was administered during the hospitalization following the delivery. In all, the cohort included 1823 women.

In order to be included in the current analysis, the women had to be the members of "Clalit" health maintenance organization (HMO), 18 years and older, and to have an available urine sample collected prior to birth and the newborns had to survive their birth hospitalization. The membership in Clalit HMO allowed the researchers an access to the subjects' medical records besides the information in the hospital system. This additional information was especially important for retrieval of pediatric diagnoses for morbidities not requiring hospitalization. Since members of the Clalit HMO represent close to $70 \%$ of the local population, this restriction is not expected to affect the generalizability of the study conclusions. In all, 1437 of the initial cohort had Clalit HMO membership.

The study hospital (SUMC) is located in Beer-Sheva, a metropolis city in the Negev desert, in southern Israel. This is the only hospital providing tertiary and outpatient services in the Negev region to a population of 1 million residents (see supplementary material, Figure 1, 
for the area map along with the subjects' residence locations).

\section{Exposure to metals}

We estimated the concentrations of 25 metals in urine samples collected prior to delivery. Samples were stored at $-20{ }^{\circ} \mathrm{C}$ prior to their testing 5 to 6 years later. An Agilent 7500 Series inductively coupled plasma mass spectrometer (ICP-MS) (Agilent Technologies, Tokyo, Japan) was used to assess the metal content of each sample. The list of metals included $\mathrm{Na}, \mathrm{K}, \mathrm{Mg}, \mathrm{Ca}, \mathrm{Zn}, \mathrm{Se}$, $\mathrm{Cu}, \mathrm{Li}, \mathrm{Co}, \mathrm{Ni}, \mathrm{Tl}, \mathrm{Al}, \mathrm{Cr}$, strontium $(\mathrm{Sr}), \mathrm{Cd}$, barium $(\mathrm{Ba})$, beryllium $(\mathrm{Be})$, vanadium $(\mathrm{V}), \mathrm{Fe}, \mathrm{As}$, molybdenium $(\mathrm{Mo}), \mathrm{Pb}$, silver $(\mathrm{Ag}), \mathrm{Mn}$, and uranium $(\mathrm{U})$. Testing was performed in a trace metal clean room, a laboratory in the Institute of Earth Sciences at the Hebrew University of Jerusalem. Values that fell below the level of quantification (LOQ) were imputed by LOQ $=0.01$ divided by the square root of two [37]. A more detailed description of the lab methodology has been reported elsewhere [38]. No adjustment was performed for creatinine, as these levels were deemed not to vary significantly within the group of all relatively young female subjects.

\section{Health outcomes}

We obtained access to all medical records prepared by local hospital and/or HMO personnel. These hospitalization records relied on the admission-transferdischarge (ATD) database and included details concerning children's complications and diagnoses during birth, subsequent hospitalizations, and emergency room and outpatient clinic visits. HMO records included visits to primary physicians, specialists' clinics, and records on all medications purchased for a child through an HMO pharmacy. It should be noted that pharmacies in Israel sell all the chronic and the majority of over-the-counter (OTC) medications, both with a substantial discount when bought with an HMO membership. For that reason, the HMO pharmacy records are expected to almost fully cover the medication purchases. The data platforms listed above represent the comprehensive list of medical records collected for each child in the analysis. Based on these sources, we were able to retrieve the complete information on diagnoses, medications, and types of clinics visited by children during the follow-up.

The following categories of morbidities were verified: preterm delivery and small-for-gestational age (SGA), malformations, asthma and cardiovascular morbidity, behavioral/developmental disorders, obesity, and malignancies.

We defined preterm delivery as delivery at a gestational age equal to or less than 37.0 weeks $[39,40]$. Of note, in the majority of deliveries, gestational age is rounded up to the whole number of weeks; therefore, gestational age "37.0" frequently included deliveries taking place a few days before 37.0. Smallfor-gestational age (SGA), defined by a diagnosis assigned to newborns at delivery, refers to newborns under the 10th percentile in weight for their gestational age [41, 42]. Malformations' diagnosis in an International Classification of Diseases 9th revision (ICD-9) system is based on the neonatologist's evaluation shortly following delivery together with diagnoses received throughout a child's encounters with the medical system, as recorded in the ATD and HMO databases (Table S2, supplementary material). Malformations' diagnoses are further classified by body systems as well as by their severity, i.e., minor or major.

Asthma-like morbidity refers to any encounters with the medical system when an ICD-9 diagnosis related to asthma was recorded or an asthma medication was purchased. The same approach was used for malignancies, cardiovascular, behavioral and developmental morbidities, and obesity. The specific codes used in the study are presented in Table S2 (supplementary material).

\section{Statistical analysis}

Metal concentrations in urine were reported as a geometric means along with a $95 \%$ confidence interval (CI) and compared by subjects' morbidity status using a ratio $t$ test in a univariate analysis (crude comparisons are not shown). Concentrations were ranked into quintiles, and their associations with health outcomes were explored visually.

We adjusted for individual risk factors using a Poisson regression model with a health outcome as a dependent variable and metal concentration in quintiles and other factors as independent parameters. We used the same list of covariates for models exploring associations with all health outcomes, and they included maternal age, parity, newborn gender, and preterm birth. Covariates in the model of preterm birth included only maternal age, parity, and newborn gender. The detailed information on the models is presented in Table S3 (supplementary material).

The point estimates of an association were expressed as relative risk (RR). In order to ensure the robustness of the model inference, we conservatively chose the sandwich estimator approach for standard error calculation. Adjusted point estimates of RR are presented in a heatmap reflecting a potential range of an effect of metals on health outcomes.

In view of the explorative nature of this analysis, performed on SAS 9.4 and $\mathrm{R}$ software, and a relatively small sample size, we did not correct for multiple comparisons. The code for the main analysis is provided (supplementary materials). 


\section{Results}

In all, 111 of women and their 111 newborns had a stored maternal urine sample available for chemical analysis. There were no twins in the sub-sample. Mothers were on average (mean \pm SD) $28.1 \pm 6.3$ years old, with more than half of them giving birth to their fourth child (Table 1). Most newborns were born at term at an average weight of $3287.3 \pm 457.5 \mathrm{~g} ; 10.8 \%$ were born at 37.0 weeks of gestation or earlier. The study follow-up fell within a range of 5.4-6.9 years, with more than half of the children underwent above 6.1 years of follow-up. Women and their offspring were not different from the main cohort, as shown in its comparison to $1437 / 1823$ women initially enrolled in the study and limited to Clalit HMO members (Table S1, supplementary materials).

Table 1 shows the list of health outcomes deemed related to environmental exposures, according to the literature. For more than half of the children, an asthmalike diagnosis was recorded in their medical charts at least once at a median age of 0.6 years, while $69.4 \%$ of all children were treated at least once for asthma-related symptoms in an emergency room or by a medication. In addition, approximately $10.8 \%$ of children at a median age of 0.8 years were referred to specialists for cardiovascular-related morbidities, although none were diagnosed with a cardiovascular disease. Over $6 \%$ of children were treated for developmental or behavioral disorders, the earliest treatment given to a 0.3 -year-old child and the latest to a 6-year-old. Overall, six were referred to an outpatient developmental clinic where one child was diagnosed with developmental delay and autism. Obesity was diagnosed in $5.4 \%$ of the sample, usually around the age of 5 years or later. There were no malignancies among the 111 children in the sample, and no mortality cases were recorded. Similar to its baseline characteristics, the population of the sub-sample did not vary from its main cohort in any of the outcomes (Table S1, supplementary material).

Table 2 shows the metal concentrations in the study population. Although, based on a small sample, their distribution does not vary from the findings reported by the authors elsewhere, alongside comparison of the obtained concentrations to the values reported in NHAN ES population [38]. However, the comparison to a sample of 31 women in Sweden [43] and a sample of 968 women in France [44] indicated excessive levels of certain metals, e.g., Se, $\mathrm{Al}, \mathrm{Co}, \mathrm{Cr}$, and $\mathrm{Pb}$ (Table 2).

Metals' concentrations by the outcomes at study are graphically described in Figures 2 a-f (supplementary material).

Women who delivered preterm were more likely to have elevated concentrations of $\mathrm{Zn}, \mathrm{Tl}, \mathrm{Al}, \mathrm{Mn}$, and $\mathrm{U}$ with an RR of 1.40-1.64 times higher compared to in term deliveries (see Table 3 and Fig. 1 showing a heatmap of the associations presented in Table 3). Cd, $\mathrm{Ni}$, and $\mathrm{Pb}$ were associated with preterm delivery, although with a borderline significance $(0.05<p$ value $<$ 0.1 ) and with comparable point estimates. Asthma was linked to high concentrations of $\mathrm{Mg}, \mathrm{Sr}$, and $\mathrm{Ba}$, all featured by a relatively small effect of RR close to 1.1. The behavioral and developmental group of disorders was the one most frequently associated with elevated metals, with the majority of them biometals, as well as $\mathrm{Li}, \mathrm{Co}$, $\mathrm{Ni}, \mathrm{Sr}, \mathrm{Cd}, \mathrm{V}$, As, and Mo. All point estimates were greater than $\mathrm{PR}=1.42$ and were different in their majority from the metals linked to preterm birth in this study.

Upon closer examination of five children with a high burden of disease (3 morbidities, etc.; see Table 1), higher concentrations were recorded for most of the metals, especially $\mathrm{Ni}$ and As. We did not identify any spatial clusters with respect to morbidity type or elevated metal concentrations.

Finally, as part of a sensitivity analysis, we investigated the possibility of a U-shape association linked to biometals and morbidities. For this purpose, we defined the exposure to a metal as a concentration in the lowest and highest quintiles (data not shown). This U-shape association was supported only in the case of $\mathrm{Ca}$ and specifically in its association with behavioral and developmental morbidities, with $\mathrm{RR}=5.62(p$ value $=0.022)$ for the lowest or highest quintiles of $\mathrm{Ca}$.

Cardiovascular outcomes and obesity were not associated with the metals, independent of other risk factors. Malformations were associated with Ag with $\mathrm{PR}=1.33$, but at a borderline significance $(p$ value $=0.094)$.

\section{Discussion}

We aimed to describe a possible link between maternal exposure to metals during gestation and pediatric morbidity in children aged 0 to 6 years. The vast majority of similar investigations done to this day were limited in the number of either metals tested for the main biomarker of exposure or pediatric morbidity [45, 46]. In contrast, 25 metals and all clinical conditions developed by children were at the investigators' disposal in the current analysis.

The study population was characterized by relatively high rates of asthma-like illness, with more than half of the children diagnosed and approximately $70 \%$ of these treated for asthma. These high rates of disease are consistent with another local study in which researchers reported comparable numbers for asthma-like symptoms in the Bedouin population [47]. Moreover, the rate of malformations was high, amounting to $9.5 \%$ in the study cohort and $7.2 \%$ in the sub-sample. It should be noted that these numbers might underestimate the actual rate, since the newborns excluded from the current analysis 
Table 1 Demographic characteristics and clinical outcomes in the study population

\begin{tabular}{|c|c|}
\hline Subjects' characteristics & $\begin{array}{l}\text { Study population } \\
(N=111 \text { newborns) } \\
(N=111 \text { deliveries }) \\
\end{array}$ \\
\hline \multicolumn{2}{|l|}{ Demography } \\
\hline \multicolumn{2}{|l|}{ Maternal age, years } \\
\hline Mean \pm SD $(n)$ & $28.1 \pm 6.3(110)$ \\
\hline Median & 26.9 \\
\hline Min; max & $18.4 ; 41.7$ \\
\hline \multicolumn{2}{|l|}{ Parity, \% $(n / M)$} \\
\hline 1 & $27.3(30 / 110)$ \\
\hline $2-5$ & $42.7(47 / 110)$ \\
\hline $6+$ & $30.0(33 / 110)$ \\
\hline \multicolumn{2}{|l|}{ Gestational age, weeks } \\
\hline Mean \pm SD $(n)$ & $39.4 \pm 1.8(111)$ \\
\hline Median & 39.0 \\
\hline Min; max & $32.0 ; 44.0$ \\
\hline \multicolumn{2}{|l|}{ Infant weight, grams } \\
\hline Mean \pm SD $(n)$ & $3287.3 \pm 457.5(111)$ \\
\hline Median & 3345.0 \\
\hline Min; max & 1725.0; 4165.0 \\
\hline Small-to-gestational age (SGA), \% (n/N) & $6.4(7 / 109)$ \\
\hline Infant male gender, $\%(n / N)$ & $54.1(60 / 111)$ \\
\hline \multicolumn{2}{|l|}{ Children's age at follow-up, years } \\
\hline Mean \pm SD $(n)$ & $6.1 \pm 0.3(111)$ \\
\hline Median & 6.1 \\
\hline Min; max & $5.4 ; 6.9$ \\
\hline \multicolumn{2}{|l|}{ Clinical outcomes, } \\
\hline Preterm delivery, \% (n/N) & $10.8(12 / 111)$ \\
\hline Malformations diagnosed at birth or follow-up, \% (n/M) & $7.2(8 / 111)$ \\
\hline \multicolumn{2}{|l|}{ Malformations' severity, \% ( $n / M)$} \\
\hline Major & $1.5(5 / 111)$ \\
\hline Minor & $2.7(3 / 111)$ \\
\hline \multicolumn{2}{|l|}{ Asthma morbidity, \% (n/N) } \\
\hline Reported as treated & $69.4(77 / 111)$ \\
\hline Diagnosed & $51.4(57 / 111)$ \\
\hline \multicolumn{2}{|l|}{ Cardiovascular morbidity, \% $(n / M)$} \\
\hline Reported as treated & $10.8(12 / 111)$ \\
\hline Diagnosed & $0(0 / 111)$ \\
\hline \multicolumn{2}{|l|}{ Behavioral conditions ${ }^{\mathrm{a}}, \%(n / \mathrm{M})$} \\
\hline Reported as treated & $6.3(7 / 111)$ \\
\hline Diagnosed & $0.9(1 / 111)$ \\
\hline \multicolumn{2}{|l|}{ Obesity, \% (n/M) } \\
\hline Reported as treated & $5.4(6 / 111)$ \\
\hline Diagnosed & $5.4(6 / 111)$ \\
\hline \multicolumn{2}{|l|}{ Burden of disease, $\%(n / M)$} \\
\hline 0 & $26.1(29 / 111)$ \\
\hline $1-2$ & $69.4(77 / 111)$ \\
\hline $3-4$ & $3.6(4 / 111)$ \\
\hline $5-6$ & $0.9(1 / 111)$ \\
\hline
\end{tabular}

a Patients who visited a developmental outpatient clinic at the ages $0.5-3$ years (in all 6 patients) and/or diagnosed with a behavioral disorder (1 patient-autism and developmental delay). 
Table 2 Internal dose of metals in the study population

\begin{tabular}{|c|c|c|c|c|c|c|c|c|c|c|}
\hline & \multirow[t]{2}{*}{$\begin{array}{l}\text { Metal } \\
(n=111)\end{array}$} & \multirow[t]{2}{*}{$\begin{array}{l}\text { Geometric } \\
\text { mean (GM) }\end{array}$} & \multirow[t]{2}{*}{$95 \% \mathrm{Cl}$} & \multirow[t]{2}{*}{ Min; $\max$} & \multicolumn{4}{|c|}{ Percentiles } & \multicolumn{2}{|c|}{$\begin{array}{l}\text { Comparison with similar } \\
\text { populations }\end{array}$} \\
\hline & & & & & 20th & 40th & 60th & 80th & $\begin{array}{l}\text { GM }(90 \text { th) } \\
21-64-y e a r-o l d \\
\text { females }(n=31)\end{array}$ & $\begin{array}{l}\mathrm{GM}(95 \% \mathrm{Cl})^{\mathrm{b}} \\
20-60 \text {-year-old } \\
\text { females }(n=968)\end{array}$ \\
\hline \multirow[t]{7}{*}{ Biometals } & Ca, ppm & 19.68 & $12.28 ; 31.53$ & $0.01 ; 287.41$ & 10.11 & 27.13 & 50.82 & 93.10 & & \\
\hline & $\mathrm{Cu}, \mathrm{ppb}$ & 12.10 & $8.55 ; 17.12$ & $\begin{array}{l}0.01 \\
2861.69\end{array}$ & 8.38 & 12.54 & 18.33 & 31.74 & $5.06(7.25)$ & \\
\hline & K, ppm & 998.88 & $604.84 ; 649.63$ & $\begin{array}{l}0.01 \\
5633.91\end{array}$ & 904.05 & 1556.99 & 2070.66 & 3228.45 & & \\
\hline & Mg, ppm & 15.17 & $9.41 ; 24.43$ & $0.01 ; 160.22$ & 10.92 & 23.84 & 40.28 & 62.66 & & \\
\hline & $\mathrm{Na}, \mathrm{ppm}$ & 1629.31 & $\begin{array}{l}969.30 \\
2738.74\end{array}$ & $\begin{array}{l}0.01 \\
10832.98\end{array}$ & 1704.94 & 2538.68 & 3615.22 & 4824.97 & & \\
\hline & Se, ppb & 19.58 & $13.73 ; 27.91$ & $0.01 ; 226.59$ & 16.54 & 22.97 & 33.18 & 47.78 & $13.1(18.3)$ & \\
\hline & $\mathrm{Zn}, \mathrm{ppb}$ & 146.51 & $93.61 ; 229.32$ & $\begin{array}{l}0.01 ; \\
4862.63\end{array}$ & 86.84 & 173.24 & 301.37 & 487.03 & $172(316)$ & $265(251-280)$ \\
\hline \multirow{18}{*}{$\begin{array}{l}\text { Non-essential } \\
\text { metals }\end{array}$} & Ag, ppb & 0.04 & $0.03 ; 0.08$ & $0.01 ; 17.13$ & 0.01 & 0.01 & 0.01 & 7.29 & & \\
\hline & Al, ppb & 6.14 & $3.80 ; 9.90$ & $0.01 ; 97.27$ & 4.34 & 11.27 & 17.17 & 26.52 & & $2.28(2.07-2.51)$ \\
\hline & As, ppb & 3.59 & $2.33 ; 5.52$ & $0.01 ; 146.21$ & 1.48 & 4.41 & 9.17 & 16.60 & $32.2(123)$ & $18.2(17.0-19.4)$ \\
\hline & $\mathrm{Ba}, \mathrm{ppb}$ & 1.29 & $0.89 ; 1.87$ & $0.01 ; 337.47$ & 0.64 & 1.32 & 2.49 & 4.40 & & \\
\hline & Be, ppb & 0.11 & $0.07 ; 0.16$ & $0.01 ; 2.63$ & 0.01 & 0.11 & 0.30 & 0.72 & & $\begin{array}{l}0.004(0.004- \\
0.005)\end{array}$ \\
\hline & $\mathrm{Cd}, \mathrm{ppb}$ & 0.20 & $0.16 ; 0.26$ & $0.01 ; 2.75$ & 0.10 & 0.20 & 0.30 & 0.50 & $0.11(0.26)$ & $0.39(0.37-0.42)$ \\
\hline & Co, ppb & 0.93 & $0.73 ; 1.19$ & $0.01 ; 4.37$ & 0.46 & 0.92 & 1.40 & 2.47 & $0.31(0.69)$ & $0.66(0.63-0.69)$ \\
\hline & $\mathrm{Cr}, \mathrm{ppb}$ & 0.63 & $0.44 ; 0.90$ & $0.01 ; 10.09$ & 0.28 & 0.71 & 1.18 & 2.19 & $0.064(0.10)$ & $0.39(0.36-0.42)$ \\
\hline & $\mathrm{Fe}, \mathrm{ppb}$ & 1.17 & $0.54 ; 2.53$ & $\begin{array}{l}0.01 \\
1640.82\end{array}$ & 0.01 & 3.33 & 16.54 & 39.43 & $2.34(5.14)$ & \\
\hline & $L i, p p b$ & 9.64 & $5.10 ; 9.52$ & $0.01 ; 74.99$ & 5.18 & 8.15 & 11.20 & 16.21 & $9.22(16.1)$ & \\
\hline & Mn, ppb & 0.03 & $0.02 ; 0.04$ & $0.01 ; 4.81$ & 0.01 & 0.01 & 0.01 & 0.39 & $0.10(0.25)$ & $0.29(0.27-0.31)$ \\
\hline & Mo, ppb & 7.23 & $3.86 ; 13.55$ & $0.01 ; 604.57$ & 4.53 & 19.64 & 34.76 & 64.20 & $31.3(63.4)$ & \\
\hline & $\mathrm{Ni}, \mathrm{ppb}$ & 1.23 & $0.95 ; 1.60$ & $0.01 ; 8.31$ & 0.65 & 1.28 & 2.20 & 3.02 & $0.91(1.57)$ & $2.10(1.98-2.21)$ \\
\hline & $\mathrm{Pb}, \mathrm{ppb}$ & 0.17 & $0.09 ; 0.32$ & $0.01 ; 62.02$ & 0.01 & 0.01 & 0.43 & 9.66 & $0.28(0.43)$ & $0.90(0.84-0.95)$ \\
\hline & $\mathrm{Sr}, \mathrm{ppb}$ & 72.73 & $48.25 ; 109.65$ & $0.01 ; 556.97$ & 45.41 & 88.50 & 135.57 & 249.20 & & \\
\hline & $\mathrm{Tl}, \mathrm{ppb}$ & 0.04 & $0.03 ; 0.05$ & $0.01 ; 0.62$ & 0.01 & 0.01 & 0.11 & 0.20 & & $0.20(0.19-0.21)$ \\
\hline & V, ppb & 0.04 & $0.03 ; 0.06$ & $0.01 ; 1.22$ & 0.01 & 0.01 & 0.10 & 0.28 & $0.011(0.018)$ & $0.24(0.22-0.26)$ \\
\hline & U, ppb & 0.01 & $0.01 ; 0.01$ & $0.01 ; 0.11$ & 0.01 & 0.01 & 0.01 & 0.01 & $1.67(2.82)$ & \\
\hline
\end{tabular}

${ }^{a}$ Swedish population

${ }^{\mathrm{b}}$ French population

due to antepartum or peripartum mortality were most probably those with major malformations [4, 34].

We recorded multiple links between morbidities and perinatal exposure to metals in both univariate and adjusted analyses. For instance, preterm delivery could be attributed to perinatal exposure to metals such as $\mathrm{Tl}, \mathrm{Al}$, and $\mathrm{U}$ as well as $\mathrm{Cd}$ and $\mathrm{Pb}-$ at significance level $<0.1$. Studies of these two metals have shown contradictory results; in other words, while some studies support the link for $\mathrm{Cd}[10,11]$ and for $\mathrm{Pb}[12]$, others do not confirm these findings [13, 14]. This inconsistency may be related to different testing matrices like a spot urine, as in case of our study, or serum [14]. These two elements are also closely related to smoking, a potential confounder of associations found. In the current study, any adjustments would not be effective, as children were exposed to second-hand smoke (from their fathers) in more than $92 \%$ of cases (data not shown).

Of note, metals linked with preterm delivery in this study were different from metals linked with behavioral and developmental outcomes, indicating some degree of specificity of exposure in its association with an outcome it may potentially produce. 
Table 3 Association between internal dose of metals in quintiles and presence of a clinical outcome at birth, adjusted to maternal and newborn clinical background and SGA',

\begin{tabular}{|c|c|c|c|c|c|c|c|}
\hline & $\begin{array}{l}\text { Metal } \\
\text { (in quintiles) }\end{array}$ & $\begin{array}{l}\text { Preterm delivery } \\
(n=12) \text { vs none } \\
(n=97)\end{array}$ & $\begin{array}{l}\text { Asthma } \\
(n=77) \text { vs } \\
\text { none }(n=34)\end{array}$ & $\begin{array}{l}\text { Cardiovascular } \\
(n=12) \text { vs none } \\
(n=99)\end{array}$ & $\begin{array}{l}\text { Behavioral or } \\
\text { developmental }(n=7) \\
\text { vs none }(n=104)\end{array}$ & $\begin{array}{l}\text { Obesity } \\
(n=6) \text { vs } \\
\text { none }(n=105)\end{array}$ & $\begin{array}{l}\text { Malformations } \\
(n=8) \text { vs none } \\
(n=103)\end{array}$ \\
\hline \multirow[t]{7}{*}{ Biometals } & Ca, ppm & $0.91(0.626)$ & $1.07(0.151)$ & $0.92(0.687)$ & $1.70(0.026)$ & $0.98(0.946)$ & $0.64(0.121)$ \\
\hline & $\mathrm{Cu}, \mathrm{ppb}$ & $1.12(0.487)$ & 1.00 (na) & $0.82(0.371)$ & $1.48(0.080)$ & $1.15(0.679)$ & $0.97(0.909)$ \\
\hline & $\mathrm{K}, \mathrm{ppm}$ & $1.21(0.198)$ & $0.98(0.637)$ & $1.11(0.640)$ & $1.51(0.095)$ & $0.87(0.634)$ & $0.86(0.599)$ \\
\hline & Mg, ppm & $0.87(0.409)$ & $1.11(0.027)$ & $0.96(0.847)$ & $2.30(0.018)$ & $1.56(0.239)$ & $1.05(0.771)$ \\
\hline & $\mathrm{Na}$, ppm & $1.20(0.204)$ & $1.00(0.999)$ & $1.01(0.969)$ & $1.93(0.016)$ & $0.91(0.740)$ & $1.14(0.584)$ \\
\hline & Se, ppb & $1.02(0.881)$ & $1.01(0.792)$ & $0.91(0.653)$ & $1.76(0.025)$ & $1.18(0.570)$ & $0.76(0.379)$ \\
\hline & $\mathrm{Zn}, \mathrm{ppb}$ & $1.50(0.033)$ & $1.00(0.997)$ & $0.81(0.357)$ & $2.11(0.022)$ & $1.27(0.483)$ & $0.91(0.751)$ \\
\hline \multirow{18}{*}{$\begin{array}{l}\text { Non-essential } \\
\text { metals }\end{array}$} & Ag, ppb & $0.89(0.500)$ & $0.98(0.534)$ & $1.05(0.771)$ & $1.27(0.273)$ & $1.27(0.273)$ & $1.33(0.094)$ \\
\hline & $\mathrm{Al}, \mathrm{ppb}$ & $1.64(0.003)$ & $1.03(0.536)$ & $0.92(0.670)$ & $1.31(0.331)$ & $1.31(0.510)$ & $1.33(0.223)$ \\
\hline & As, ppb & $1.11(0.516)$ & $1.01(0.794)$ & $1.05(0.820)$ & $1.49(0.041)$ & $1.18(0.614)$ & $1.33(0.344)$ \\
\hline & $\mathrm{Ba}, \mathrm{ppb}$ & $1.20(0.300)$ & $1.14(0.004)$ & $0.80(0.262)$ & $1.19(0.503)$ & $1.30(0.565)$ & $0.69(0.191)$ \\
\hline & $\mathrm{Be}, \mathrm{ppb}$ & $0.74(0.091)$ & $1.06(0.209)$ & $0.95(0.775)$ & $1.21(0.270)$ & $0.85(0.653)$ & $1.15(0.579)$ \\
\hline & $\mathrm{Cd}, \mathrm{ppb}$ & $1.45(0.084)$ & $0.99(0.874)$ & $1.07(0.760)$ & $1.70(<0.001)$ & $1.15(0.702)$ & $1.05(0.856)$ \\
\hline & Co, ppb & $1.07(0.638)$ & $0.99(0.892)$ & $1.03(0.888)$ & $2.06(0.003)$ & $0.76(0.208)$ & $0.95(0.830)$ \\
\hline & $\mathrm{Cr}, \mathrm{ppb}$ & $1.21(0.302)$ & $1.04(0.323)$ & $0.78(0.171)$ & $1.02(0.938)$ & $0.74(0.379)$ & $0.75(0.239)$ \\
\hline & Fe, ppb & $1.22(0.202)$ & $1.05(0.238)$ & $0.87(0.511)$ & $1.42(0.080)$ & $1.05(0.936)$ & $0.89(0.623)$ \\
\hline & $\mathrm{Li}, \mathrm{ppb}$ & $0.92(0.559)$ & $1.01(0.853)$ & $1.09(0.672)$ & $1.82(0.010)$ & $0.85(0.467)$ & $1.00(0.998)$ \\
\hline & $\mathrm{Mn}, \mathrm{ppb}$ & $1.59(<0.001)$ & $1.02(0.585)$ & $0.99(0.942)$ & $1.15(0.441)$ & $1.33(0.258)$ & $1.17(0.331)$ \\
\hline & Mo, ppb & $1.32(0.129)$ & $0.96(0.315)$ & $1.04(0.856)$ & $1.86(0.016)$ & $1.07(0.796)$ & $0.89(0.655)$ \\
\hline & $\mathrm{Ni}, \mathrm{ppb}$ & $1.28(0.090)$ & 1.00 (na) & $0.98(0.942)$ & $2.14(0.014)$ & $1.06(0.837)$ & $1.06(0.809)$ \\
\hline & $\mathrm{Pb}, \mathrm{ppb}$ & $1.28(0.087)$ & $1.06(0.147)$ & $0.86(0.387)$ & $1.19(0.315)$ & $1.19(0.315)$ & $0.99(0.953)$ \\
\hline & Sr, ppb & $1.01(0.972)$ & $1.10(0.029)$ & $0.95(0.813)$ & $2.69(0.009)$ & $1.18(0.553)$ & $0.92(0.758)$ \\
\hline & $\mathrm{Tl}, \mathrm{ppb}$ & $1.48(0.013)$ & $0.96(0.394)$ & $1.03(0.874)$ & $1.64(0.191)$ & $1.11(0.718)$ & $1.26(0.390)$ \\
\hline & V, ppb & $1.16(0.292)$ & 1.00 (na) & $0.97(0.842)$ & $1.71(0.017)$ & $0.98(0.961)$ & $1.04(0.826)$ \\
\hline & U, ppb & $1.40(0.009)$ & $0.99(0.821)$ & $1.04(0.808)$ & $0.96(0.839)$ & $0.96(0.839)$ & $0.96(0.849)$ \\
\hline \multicolumn{2}{|c|}{ Covariates in the model } & $\begin{array}{l}\text { Maternal age, parity, } \\
\text { newborn gender }\end{array}$ & \multicolumn{5}{|c|}{$\begin{array}{l}\text { Maternal age, parity, newborn } \\
\text { gender, preterm birth }\end{array}$} \\
\hline
\end{tabular}

${ }^{1}$ The table presents a relative risk (RR) reflecting a risk of a health outcome as a function of metals concentrations

${ }^{2}$ na - not available based on the current analysis

Our analysis of behavioral outcomes showed a link to a slightly different set of metals, including $\mathrm{Li}, \mathrm{Co}, \mathrm{Ni}, \mathrm{Sr}$, $\mathrm{V}$, As, Mo, and Cd. We found no previous studies that explored the association of these metals with behavioral morbidity; most focus on $\mathrm{Cd}$ and $\mathrm{Pb}[15-17,20,21]$. These together with the metals linked to preterm delivery may all represent industry-related exposure. An additional exploration of morbidity cases did not reveal any residential clusters, although our sub-sample was too small for any meaningful epidemiological investigation of an exposure source.

Despite the fact that an asthma-like illness outcome was not associated with exposure to metals with the exception of $\mathrm{Mg}, \mathrm{Sr}$, and $\mathrm{Ba}$, this outcome occurred so commonly as to produce a valid analysis specific to the cause. Malformations were found to be related only to
Ag, but at a borderline significance $(p$ value $<0.1)$ when adjusted for other factors. The current study adds to the findings of a relatively short list of studies on the association of metal with birth defects: one shows an adverse effect of $\mathrm{As}, \mathrm{Pb}, \mathrm{Cd}$, and $\mathrm{Cu}$ on neural tube defects in infants [48], another adversely links exposure to Li use in pregnancy with cardiac malformations [49], and a third, focusing on a different sub-sample of the current cohort, shows the adverse association of $\mathrm{Al}$ with minor malformations at birth [4]. As previously stated, the malformations we observed do not represent the complete picture of this morbidity; therefore, the current analysis is likely biased toward less severe cases.

Our findings on non-essential metals partially confirm existing theories on their U-shaped impact, i.e., whereas an element should be present within its normal range, 


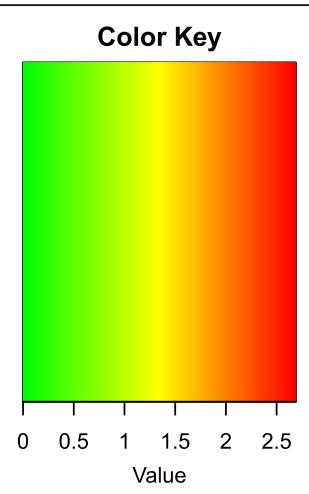

\section{Relative Risk}

\begin{tabular}{ccccccc|}
\hline 1.2 & 1 & 1.01 & 1.93 & 0.91 & 1.14 & $\mathrm{Na}$ \\
1.16 & 1 & 0.97 & 1.71 & 0.98 & 1.04 & $\mathrm{~V}$ \\
1.32 & 0.96 & 1.04 & 1.86 & 1.07 & 0.89 & $\mathrm{Mo}$ \\
1.48 & 0.96 & 1.03 & 1.64 & 1.11 & 1.26 & $\mathrm{Tl}$ \\
1.45 & 0.99 & 1.07 & 1.7 & 1.15 & 1.05 & $\mathrm{Cd}$ \\
1.5 & 1 & 0.81 & 2.11 & 1.27 & 0.91 & $\mathrm{Zn}$ \\
1.28 & 1 & 0.98 & 2.14 & 1.06 & 1.06 & $\mathrm{Ni}$ \\
\hline 1.02 & 1.01 & 0.91 & 1.76 & 1.18 & 0.76 & $\mathrm{Se}$ \\
0.91 & 1.07 & 0.92 & 1.7 & 0.98 & 0.64 & $\mathrm{Ca}$ \\
1.21 & 0.98 & 1.11 & 1.51 & 0.87 & 0.86 & $\mathrm{~K}$ \\
1.07 & 0.99 & 1.03 & 2.06 & 0.76 & 0.95 & $\mathrm{Co}$ \\
0.92 & 1.01 & 1.09 & 1.82 & 0.85 & 1 & $\mathrm{Li}$ \\
1.01 & 1.1 & 0.95 & 2.69 & 1.18 & 0.92 & $\mathrm{Sr}$ \\
0.87 & 1.11 & 0.96 & 2.3 & 1.56 & 1.05 & $\mathrm{Mg}$ \\
\hline 1.22 & 1.05 & 0.87 & 1.42 & 1.05 & 0.89 & $\mathrm{Fe}$ \\
1.12 & 1 & 0.82 & 1.42 & 1.15 & 0.97 & $\mathrm{Cu}$ \\
1.28 & 1.06 & 0.86 & 1.19 & 1.1 & 0.99 & $\mathrm{~Pb}$ \\
1.2 & 1.14 & 0.8 & 1.19 & 1.3 & 0.69 & $\mathrm{Ba}$ \\
1.21 & 1.04 & 0.78 & 1.02 & 0.74 & 0.75 & $\mathrm{Cr}$ \\
1.11 & 1.01 & 1.05 & 1.49 & 1.18 & 1.33 & $\mathrm{As}$ \\
0.89 & 0.98 & 1.05 & 1.27 & 1.08 & 1.33 & $\mathrm{Ag}$ \\
0.74 & 1.06 & 0.95 & 1.21 & 0.85 & 1.15 & $\mathrm{Be}$ \\
1.64 & 1.03 & 0.92 & 1.31 & 1.31 & 1.33 & $\mathrm{Al}$ \\
1.59 & 1.02 & 0.99 & 1.15 & 1.33 & 1.17 & $\mathrm{Mn}$ \\
1.4 & 0.99 & 1.04 & 0.96 & 0 & 0.96 & $\mathrm{U}$ \\
\hline & & & & & &
\end{tabular}
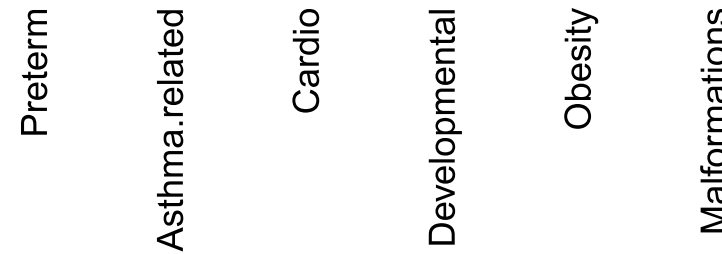

Fig. 1 Heatmap of association between internal dose of metals in quintiles and presence of a clinical outcome at birth, adjusted to maternal and newborn clinical background and expressed as relative risk (the color scale ranges from green assigned to protective factors to red assigned to risk factors with relative risk $>1$ )

and levels too low or too high may present a risk factor for health [1]. We recorded this type of association only for $\mathrm{Ca}$ and developmental outcomes, but not for other elements. At the same time, cardiovascular outcome was only negatively associated with essential metals, i.e., subjects with a cardiovascular outcome were more likely to have low levels of $\mathrm{Zn}$. However, this finding was not confirmed in a multivariable analysis.

Our sample was almost identical to that of the study cohort in terms of baseline characteristics and morbidity 
rates. This similarity confirms the appropriateness of the subgroup's random selection, as well as enables the extrapolation of our conclusions to a larger population.

The current analysis has few limitations, the most obvious being its relatively small size and non-conservative approach which precludes correction of significance levels to the investigation of multiple metals and outcomes; this approach corresponds to the explorative nature of our analysis and promoted some hypothesisgenerating findings worthy of further investigation.

A further limitation concerns possible misclassification based on our definitions of morbidity, where an outcome is defined by a diagnosis recorded at any point in life or treatment ever administered if deemed related to that disease. This is a frequent pitfall of definitions based on medical records, which although tending to attenuate measured associations toward the null hypothesis are not expected to bias study conclusions.

Lastly, we investigated a sample of Bedouin-Arab women and their offspring who differ in levels of hazardous exposures from the neighboring Jewish population, yet are treated by the same health services. Nevertheless, links between objectively measured metal concentrations and morbidity based on medical records rather than on self-reporting, adjusted to main risk factors, should not be limited to this ethnic group but should also hold true for other populations.

To conclude, the current study offers an analysis of a large number (25 in all) of metals that to date have not been explored for their relation to pediatric morbidity. Behavioral and developmental disorders and preterm delivery were associated with heavy metals detected in maternal urine at pregnancy, independent of other factors.

Our analysis provides many hypotheses-generating findings that warrant further exploration on a larger sample.

\section{Abbreviations \\ Ag: Silver; Al: Aluminum; As: Arsenic; Ba: Barium; Be: Beryllium; Ca: Calcium; Cd: Cadmium; Cr: Chromium; Co: Cobalt; Cu: Copper; Fe: Iron; Hg: Mercury; K: Potassium; Mg: Magnesium; Mn: Manganese; Mo: Molybdenum; Na: Sodium; Ni: Nickel; Pb: Lead; Se: Selenium; Sr: Strontium; Ti: Titanium; U: Uranium; V: Vanadium; Zn: Zinc; ATD: Admission-transfer-discharge; Cl: Confidence interval; HMO: Health maintenance organization; ICD- 9: International Classification of Diseases 9th revision; ICP-MS: Inductively coupled plasma mass spectrometer; LOQ: Level of quantification; NHAN ES: National Health and Nutrition Examination Survey; OTC: Over-the-counter; RR: Relative risk; SGA: Small-for-gestational age; SUMC: Soroka University Medical Center}

\section{Supplementary Information}

The online version contains supplementary material available at https://doi. org/10.1186/s12199-021-00963-z.

Additional file 1: Table S1: Demographic characteristics and clinical outcomes in the study population and the initial cohort, Clalit HMO members
Additional file 2: Table S2: ICD-9 codes used for health outcome definitions

Additional file 3: Table S3: Association between maternal and newborn clinical background and presence of a clinical outcome at birth

Additional file 4: Figure S1: Study area map and geographical distribution of the study population. Figure legend: the blue dots in the map represent the subjects' residence location. (JPEG $45 \mathrm{~kb}$ )

Additional file 5: Figure S2: Graphical presentation of the metal concentrations by outcomes

Additional file 6 .

\section{Authors' contributions}

IK and BS are the epidemiologists who conceived the idea of the study and wrote the study protocol. IK has supervised the methodological aspects of the study implementation and participated in the analysis of the study findings. DL is the pediatrician who contributed her knowledge to understanding of the clinical aspects of the study question and the data analysis. MYS coordinated the first phase of the data collection, and RG coordinated the second phase of the study. NS and OT developed the protocol for testing and accomplished the testing phase. LN is the principal investigator of the study who participated in the study planning, supervised the study progress, analyzed the data, and wrote the first draft of the manuscript. The authors read and approved the final manuscript.

\section{Funding}

This study was partially supported by grant no. 3-7298 from the Public Committee for Allocation of Estate Funds, Ministry of Health, Israel.

\section{Availability of data and materials}

Data supporting the findings will be provided upon request and only following an approval by the local IRB committee.

\section{Declarations}

Ethics approval and consent to participate

The study has been approved by the MDA scientific committee and the IRB of Soroka University Medical Center. The informed consent to participate in the study was signed by all the participants.

Consent for publication

Not relevant.

\section{Competing interests}

The authors declare no that they have no competing interest.

\section{Author details}

'Environmental Epidemiology, Ministry of Health, Jerusalem, Israel. ${ }^{2}$ Neonatology Department, Soroka University Medical Center, Beer-Sheva, Israel. ${ }^{3}$ Clinical Research Center, Soroka University Medical Center, Beer-Sheva, Israel. ${ }^{4}$ Faculty of Health Sciences, Ben-Gurion University of the Negev, Beer-Sheva, Israel. ${ }^{5}$ Department of Clinical Biochemistry and Pharmacology, Ben-Gurion University of the Negev, Beer-Sheva, Israel. ${ }^{6}$ The Fredy and Nadine Herrmann Institute of Earth Sciences, The Hebrew University of Jerusalem, Jerusalem, Israel. " Department of Environmental Health, Harvard T.H. Chan School of Public Health, Boston, USA. ${ }^{8}$ Department of Public Health, Ben-Gurion University of the Negev, Beer-Sheva, Israel. ${ }^{9} \mathrm{Negev}$ Environmental Health Research Institute, Soroka University Medical Center, Sderot Rager 151, 84101 Beer-Sheva, Israel.

Received: 24 November 2020 Accepted: 12 March 2021

Published online: 25 March 2021

\section{References}

1. Caito S, Aschner M. Neurotoxicity of metals. Handb Clin Neurol. 2015;131: 169-89. https://doi.org/10.1016/B978-0-444-62627-1.00011-1.

2. Pokusa M, Králová Trančíková A. The central role of biometals maintains oxidative balance in the context of metabolic and neurodegenerative disorders. Oxid Med Cell Longev. 2017. 
3. Arruda MAZ. Metallomics: the sience of biometals. Sao Paolo: Springer; 2018. https://doi.org/10.1007/978-3-319-90143-5.

4. Karakis I, Landau D, Yitshak-Sade M, Hershkovitz R, Rotenberg M, Sarov B, Grotto I, Novack L. Exposure to metals and congenital anomalies: a biomonitoring study of pregnant Bedouin-Arab women. Sci Total Environ. 2015 Jun 1:517:106-12. https://doi.org/10.1016/j.scitotenv.2015.02.056.

5. Liu Z, Lin Y, Tian X, Li J, Chen X, Yang J, Li X, Deng Y, Li N, Liang J, Li S, Zhu J. Association between maternal aluminum exposure and the risk of congenital heart defects in offspring. Birth Defects Res A Clin Mol Teratol. 2016 Feb;106(2):95-103. https://doi.org/10.1002/bdra.23464.

6. Jin X, Tian X, Liu Z, Hu H, Li X, Deng Y, Li N, Zhu J. Maternal exposure to arsenic and cadmium and the risk of congenital heart defects in offspring. Reprod Toxicol. 2016 Jan;59:109-16. https://doi.org/10.1016/j.reprotox.201 5.12.007.

7. White JT, Kovar E, Chambers TM, et al. Hypospadias risk from maternal residential exposure to heavy metal hazardous air pollutants. Int J Environ Res Public Health. 2019;16:6.

8. Deyssenroth MA, Gennings C, Liu SH, Peng S, Hao K, Lambertini L, Jackson $\mathrm{BP}$, Karagas MR, Marsit CJ, Chen J. Intrauterine multi-metal exposure is associated with reduced fetal growth through modulation of the placental gene network. Environ Int. 2018 Nov;120:373-81. https://doi.org/10.1016/j. envint.2018.08.010

9. Thomas S, Arbuckle TE, Fisher M, Fraser WD, Ettinger A, King W. Metals exposure and risk of small-for-gestational age birth in a Canadian birth cohort: The MIREC study. Environ Res. 2015 Jul;140:430-9. https://doi.org/1 0.1016/j.envres.2015.04.018

10. Tsuji M, Shibata E, Morokuma S, Tanaka R, Senju A, Araki S, Sanefuji M, Koriyama C, Yamamoto M, Ishihara Y, Kusuhara K, Kawamoto T, Saito H, Kishi R, Yaegashi N, Hashimoto K, Mori C, Ito S, Yamagata Z, Inadera H, Kamijima M, Nakayama T, Iso H, Shima M, Hirooka Y, Suganuma N, Kusuhara K, Katoh T. The association between whole blood concentrations of heavy metals in pregnant women and premature births: The Japan Environment and Children's Study (JECS). Environ Res. 2018;166:562-9. https://doi.org/10.1 016/j.envres.2018.06.025.

11. Wai KM, Mar O, Kosaka S, et al. Prenatal heavy metal exposure and adverse birth outcomes in myanmar: a birth-cohort study. I. Int J Environ Res Public Health. 2017;14:11.

12. Li J, Wang H, Hao JH, Chen YH, Liu L, Yu Z, Fu L, Tao FB, Xu DX. Maternal serum lead level during pregnancy is positively correlated with risk of preterm birth in a Chinese population. Environ Pollut. 2017 Aug;227:484-9. https://doi.org/10.1016/j.envpol.2017.05.009.

13. Perkins M, Wright RO, Amarasiriwardena CJ, Jayawardene I, Rifas-Shiman SL, Oken E. Very low maternal lead level in pregnancy and birth outcomes in an eastern Massachusetts population. Ann Epidemiol. 2014;24(12):915-9. https://doi.org/10.1016/j.annepidem.2014.09.007.

14. Yu Y, Gao M, Wang X, Guo Y, Pang Y, Yan H, Hao Y, Zhang Y, Zhang L, Ye R, Wang B, Li Z. Recommended acceptable levels of maternal serum typical toxic metals from the perspective of spontaneous preterm birth in Shanxi Province. China. Sci Total Environ. 2019;686:599-605. https://doi.org/10.1016/ j.scitotenv.2019.05.413.

15. Allen KA. Is prenatal lead exposure a concern in infancy? What is the evidence? Adv Neonatal Care. 2015;15(6):416-20. https://doi.org/10.1097/A NC.0000000000000224.

16. Lin Y, Huang L, Xu J, Specht AJ, Yan C, Geng H, Shen X, Nie LH, Hu H. Blood lead, bone lead and child attention-deficit-hyperactivity-disorder-like behavior. Sci Total Environ. 2019;659:161-7. https://doi.org/10.1016/j. scitotenv.2018.12.219.

17. Ji Y, Hong X, Wang G, Chatterjee N, Riley AW, Lee LC, Surkan PJ, Bartell TR, Zuckerman B, Wang X. A prospective birth cohort study on early childhood lead levels and attention deficit hyperactivity disorder: new insight on sex differences. J Pediatr. 2018;199:124-31. https://doi.org/10.1016/j.jpeds.2018. 03.076 .

18. Bjørklund G, Chartrand MS, Aaseth J. Manganese exposure and neurotoxic effects in children. Environ Res. 2017;155:380-4. https://doi.org/10.1016/j. envres.2017.03.003

19. Freire C, Amaya E, Gil F, et al. Prenatal co-exposure to neurotoxic metals and neurodevelopment in preschool children: The Environment and Childhood (INMA) Project. Sci Total Environ. 2018;15(621):340-51.

20. Hsueh YM, Lee CY, Chien SN, Chen WJ, Shiue HS, Huang SR, Lin MI, Mu SC, Hsieh RL. Association of blood heavy metals with developmental delays and health status in children. Sci Rep. 2017;7(1):43608. https://doi.org/10.1038/ srep43608.

21. Kippler M, Bottai M, Georgiou V, Koutra K, Chalkiadaki G, Kampouri M, Kyriklaki A, Vafeiadi M, Fthenou E, Vassilaki M, Kogevinas M, Vahter M, Chatzi L. Impact of prenatal exposure to cadmium on cognitive development at preschool age and the importance of selenium and iodine. Eur J Epidemiol. 2016;31(11):1123-34. https://doi.org/10.1007/s10654-016-0151-9.

22. Rahman SM, Kippler MM, Tofail F, et al. Manganese in drinking water and cognitive abilities and behavior at 10 years of age: a prospective cohort study. Environ Health Perspect. 2017;125(5):057003. https://doi.org/10.1289/ EHP631.

23. Kordas K, Ardoino G, Coffman DL, et al. Patterns of exposure to multiple metals and associations with neurodevelopment of preschool children from Montevideo. Uruguay. J Environ Public Health. 2015;493471.

24. Forns J, Fort M, Casas M, Cáceres A, Guxens M, Gascon M, Garcia-Esteban R, Julvez J, Grimalt JO, Sunyer J. Exposure to metals during pregnancy and neuropsychological development at the age of 4 years. Neurotoxicology. 2014;40:16-22. https://doi.org/10.1016/j.neuro.2013.10.006.

25. Ashrap P, Watkins DJ, Mukherjee B, et al. Predictors of urinary and blood metal(loid) concentrations among pregnant women in Northern Puerto Rico. Environ Res. 2020 04;183:109178.

26. Shah S, Jeong KS, Park H, et al. Environmental pollutants affecting children's growth and development: collective results from the MOCEH study, a multicentric prospective birth cohort in Korea. Environ Int. 2020 04;137:105547.

27. Wu KG, Chang CY, Yen CY, Lai CC. Associations between environmental heavy metal exposure and childhood asthma: a population-based study. J Microbiol Immunol Infect. 2019;52(2):352-62. https://doi.org/10.1016/j.jmii.2 018.08.001.

28. Wang IJ, Karmaus WJ, Yang CC. Lead exposure, IgE, and the risk of asthma in children. J Expo Sci Environ Epidemiol. 2017;27(5):478-83. https://doi. org/10.1038/jes.2017.5.

29. Madrigal JM, Persky V, Pappalardo A, Argos M. Association of heavy metals with measures of pulmonary function in children and youth: results from the National Health and Nutrition Examination Survey (NHANES). Environ Int. 2018;121(Pt 1):871-8. https://doi.org/10.1016/j.envint.2018.09.045.

30. Rosa MJ, Benedetti C, Peli M, Donna F, Nazzaro M, Fedrighi C, Zoni S, Marcon A, Zimmerman N, Wright R, Lucchini R. Association between personal exposure to ambient metals and respiratory disease in Italian adolescents: a cross-sectional study. BMC Pulm Med. 2016 12;16(1):6. https:// doi.org/10.1186/s12890-016-0173-9.

31. Gehring U, Beelen R, Eeftens M, Hoek G, de Hoogh K, de Jongste JC, Keuken M, Koppelman GH, Meliefste K, Oldenwening M, Postma DS, van Rossem L, Wang M, Smit HA, Brunekreef B. Particulate matter composition and respiratory health: the PIAMA Birth Cohort study. Epidemiology. 2015;26(3): 300-9. https://doi.org/10.1097/EDE.0000000000000264.

32. Farzan SF, Howe CG, Chen Y, Gillbert-Diamond D, Cottingham KL, Jackson BP, Weinstein AR, Karagas MR. Prenatal lead exposure and elevated blood pressure in children. Environ Int. 2018;121(Pt 2):1289-96. https://doi.org/10.1 016/.envint.2018.10.049.

33. Green AJ, Hoyo C, Mattingly CJ, Luo Y, Tzeng JY, Murphy SK, Buchwalter DB, Planchart A. Cadmium exposure increases the risk of juvenile obesity: a human and zebrafish comparative study. Int J Obes. 2018;42(7):1285-95. https://doi.org/10.1038/s41366-018-0036-y.

34. Treister-Goltzman Y, Peleg R. What is known about health and morbidity in the pediatric population of Muslim Bedouins in Southern Israel: a descriptive review of the literature from the past two decades. J Immigr Minor Health. 2015;17(2):940-6. https://doi.org/10.1007/s10903-014-0001-3.

35. Landau D, Novack L, Yitshak-Sade M, Sarov B, Kloog I, Hershkovitz R, Grotto I, Karakis I. Nitrogen dioxide pollution and hazardous household environment: what impacts more congenital malformations. Chemosphere. 2015;139:340-8. https://doi.org/10.1016/j.chemosphere.2015.06.091.

36. Yitshak-Sade M, Novack L, Landau D, Kloog I, Sarov B, Hershkovitz R, Karakis I. Relationship of ambient air pollutants and hazardous household factors with birth weight among Bedouin-Arabs. Chemosphere. 2016;160:314-22. https://doi.org/10.1016/j.chemosphere.2016.06.104.

37. Baccarelli A, Pfeiffer R, Consonni D, Pesatori AC, Bonzini M, Patterson DG Jr, Bertazzi PA, Landi MT. Handling of dioxin measurement data in the presence of non-detectable values: overview of available methods and their application in the Seveso chloracne study. Chemosphere. 2005;60(7):898906. https://doi.org/10.1016/..chemosphere.2005.01.055. 
38. Karakis I, Shemesh N, Tirosh O, et al. Assessment of household and outdoor air pollution exposure link to urinary metals content in pregnant women. Atmosphere. 2020;11:638.

39. Preterm birth. World Health Organization: Fact Sheets2019.

40. Preterm Labor and Birth: Condition Information: National Institutes of Health; 2017 [cited 2021 February 13]. Available from: https://www.nichd.nih.gov/ health/topics/preterm/conditioninfo/default

41. de Onis M, Habicht JP. Anthropometric reference data for international use: recommendations from a World Health Organization Expert Committee. Am J Clin Nutr. 1996;64(4):650-8. https://doi.org/10.1093/ajcn/64.4.650.

42. Physical status : the use of and interpretation of anthropometry, report of a WHO expert committee. 1995.

43. Barregard L, Ellingsen DG, Berlinger B, Weinbruch S, Harari F, Sallsten G. Normal variability of 22 elements in 24 -hour urine samples - results from a biobank from healthy non-smoking adults. Int J Hyg Environ Health. 2021; 233:113693. https://doi.org/10.1016/j.jiheh.2021.113693.

44. Nisse C, Tagne-Fotso R, Howsam M, et al. Blood and urinary levels of metals and metalloids in the general adult population of Northern France: The IMEPOGE study, 2008-2010. Int J Hyg Environ Health. 2017;220(2 Pt B):34163.

45. Tsai MS, Chen MH, Lin CC, et al. Children's environmental health based on birth cohort studies of Asia (2) - air pollution, pesticides, and heavy metals. Environ Res. 2019;179(Pt A):108754.

46. Al-Saleh I, Shinwari N, Mashhour A, et al. Birth outcome measures and maternal exposure to heavy metals (lead, cadmium and mercury) in Saudi Arabian population. Int J Hyg Environ Health. 2014;217(2-3):205-18. https:// doi.org/10.1016/j.j.jheh.2013.04.009.

47. Yitshak-Sade M, Novack V, Katra I, Gorodischer R, Tal A, Novack L. Nonanthropogenic dust exposure and asthma medication purchase in children. Eur Respir J. 2015;45(3):652-60. https://doi.org/10.1183/09031936.00078614.

48. Demir N, Başaranoğlu M, Huyut Z, Değer I, Karaman K, Şekeroğlu MR, Tuncer $\mathrm{O}$. The relationship between mother and infant plasma trace element and heavy metal levels and the risk of neural tube defect in infants. J Matern Fetal Neonatal Med. 2019;32(9):1433-40. https://doi.org/1 $0.1080 / 14767058.2017 .1408064$

49. Florio AD, Munk-Olsen T, Bergink V. The birth of a psychiatric orphan disorder: postpartum psychosis. Lancet Psychiatry. 2016;3(6):502. https://doi. org/10.1016/S2215-0366(16)30037-2.

\section{Publisher's Note}

Springer Nature remains neutral with regard to jurisdictional claims in published maps and institutional affiliations.

Ready to submit your research? Choose BMC and benefit from:

- fast, convenient online submission

- thorough peer review by experienced researchers in your field

- rapid publication on acceptance

- support for research data, including large and complex data types

- gold Open Access which fosters wider collaboration and increased citations

- maximum visibility for your research: over $100 \mathrm{M}$ website views per year

At $\mathrm{BMC}$, research is always in progress.

Learn more biomedcentral.com/submissions 